\title{
Expression and Purification of Glutamine Synthetase Cloned from Bacteroides fragilis
}

\author{
By JAMES A. SOUTHERN, ${ }^{1}$ JOAN R. PARKER ${ }^{2}$ AND DAVID R. WOODS ${ }^{2 *}$ \\ ${ }^{1}$ State Vaccine Institute, Alexandra Road. Pinelands, 7405, South Africa \\ 2Department of Microbiology, University of Cape Town, Rondebosch 7700, South Africa
}

(Received 3 February 1986; revised 7 May 1986)

\begin{abstract}
A glutamine synthetase (GS) gene, $g \ln A$, from Bacteroides fragilis was cloned on a recombinant plasmid pJSI 39 which enabled Escherichia coli glnA deletion mutants to utilize $\left(\mathrm{NH}_{4}\right)_{2} \mathrm{SO}_{4}$ as a sole source of nitrogen. DNA homology was not detected between the $B$. fragilis gln $A$ gene and the $E$. coligln $A$ gene. The cloned $B$. fragilis $g \ln A$ gene was expressed from its own promoter and was subject to nitrogen repression in $E$. coli, but it was not able to activate histidase activity in an $E$. coli glnA ntrB ntrC deletion mutant containing the Klebsiella aerogenes hut operon. The GS produced by pJS139 in $E$. coli was purified: it had an apparent subunit $M_{\mathrm{r}}$ of approximately 75000 , which is larger than that of any other known bacterial GS. There was very slight antigenic cross-reactivity between antibodies to the purified cloned B. fragilis GS and the GS subunit of wild-type $E$. coli.
\end{abstract}

\section{INTRODUCTION}

The medically important obligate anaerobe Bacteroides fragilis is under investigation with regard to its genetic constitution, particularly the potential for the transfer of genetic material to the other microbial inhabitants of the mammalian gut. There has been some doubt regarding the possibility of expression of Bacteroides genes in other bacteria following a report by Guiney et al. (1984) which indicated that the ampicillin resistance gene from Escherichia coli was not expressed in $B$. fragilis and that the clindamycin resistance gene from the $B$. fragilis pBFTM 10 plasmid was not expressed in $E$. coli. However, the cloning and expression in $E$. coli of the fimbrial sub-unit protein, pilin protein, cellulase and chondroitin lyase genes from Bacteroides nodosus, Bacteroides succinogenes and Bacteroides thetaiotaomicron have been reported (Anderson et al., 1984; Crosby \& Collier, 1984: Elleman \& Hoyne. 1984; Guthrie et al., 1985).

Since $B$. fragilis is the anaerobic species most frequently isolated from human infections (Kasper et al., 1979) we investigated the expression of its genes in E. coli. Glutamine synthetase (GS) is a central enzyme in the pathways of nitrogen metabolism for many bacteria and as its presence in $\boldsymbol{B}$. fragilis was expected a gene library prepared from $\boldsymbol{B}$. fragilis strain $\mathrm{BF}-1$ was screened for expression of GS.

In the Enterobacteriaceae the structural gene for GS, $g \ln A$, is regulated by the products of the $n \operatorname{tr} B$ and $n \operatorname{tr} C$ genes which are linked to the $g \ln A$ gene, and by the product of the unlinked $n t r A$ gene (Garcia et al., 1977: Kustu et al.. 1979: Pahel \& Tyler, 1979: McFarland et al., 1981; Magasanik, 1982). The $n t r$ genes also regulate other operons involved in nitrogen metabolism.

GS from several bacterial genera has been purified utilizing the large size and heat resistance of the holoenzyme to separate it from other intracellular macromolecules (Streicher \& Tyler, 1980; Bodasing et al., 1985). We report the use of polyethylene glycol (PEG) and column chromatography for the purification of the cloned GS and describe the production of specific antibodies in rabbits.

Abbreviation: GS, glutamine synthetase. 


\section{Table 1. Bacterial strains and plasmids}

Strain

B. fragilis BF-1

E. coli $\mathrm{ET} 8051$

E. coli YMC-10

E. coli YMC-11

E. coli $\mathrm{HB}-101$

Plasmids

pEcoR251

$\mathrm{pcI}_{857}$

pJS139

pJS139.1

pJS139.2
Relevant genotype

Wild-type bacteriocin ${ }^{+}$

$g \ln A$ ntr $B$ ntrC

$g \ln A^{+} n \operatorname{tr} B^{+} n \operatorname{tr} C^{+}$

$g \ln A \operatorname{ntr} B$ ntr $C$

$\operatorname{Str}^{r} g \ln A^{+} n t r B^{+} n t r C^{+}$

Apr $E c o$ RI

$\operatorname{Kan}^{\mathrm{r}} \lambda-\mathrm{P}_{\mathrm{R}}$ repressor(ts)

$\mathrm{Ap}^{\mathrm{r}} g \ln A^{+}$

$\mathrm{Ap}^{\mathrm{r}} \operatorname{gln} A$ (XhoI deletion)

$\mathrm{Ap}^{\mathrm{r}} \operatorname{gln} A^{+}$(StuI deletion)

\section{Reference/source}

Mossie et al. (1979)

Tuli et al. (1982)

Backman et al. (1981)

Backman et al. (1981)

Maniatis et al. (1982)

M. M. Zabaeu, Plant Genetic

Systems, Ghent, Belgium

This study

\section{METHODS}

Bacterial strains and plasmids. B. fragilis strain BF-I was described by Mossie et al. (1979). The plasmid pEcoR251 was a gift from M. M. Zabeau, Plant Genetic Systems, Ghent, Belgium. This positive selection vector contains the $E$. coli $E c o$ RI gene under the control of the $\lambda$ rightward promoter, the ampicillin (Ap) resistance gene and the pBR322 origin of replication. It was derived from the pCL plasmids described by Zabeau \& Stanley (1982). The EcoRI gene product, expressed at high levels by the $\lambda$ promoter on pEcoR251, is lethal unless insertionally inactivated or regulated by plasmid $\mathrm{pcI}_{857}$ which contains a temperature-sensitive $\lambda$ repressor gene (Remaut et al., 1983). The EcoRI gene has a single BglII restriction enzyme site which can be used for the insertion of DNA digested with BglII, BamHI or Sau3AI. The E. coli strains used are described in Table 1.

$B$. fragilis was grown under anaerobic conditions in a complex medium which contained $\left(\mathrm{g}^{-1}\right)$ Difco tryptic soy broth (24), Difco yeast extract (10), glucose (1) and L-cysteine hydrochloride (0.5) (Southern et al., 1984). The $E$. coli strains were grown in LB (Luria-Bertani) broth containing $\left(\mathrm{g}^{-1}\right.$ ) Difco Bacto-tryptone (10), Difco yeast extract (5) and $\mathrm{NaCl}$ (5) (Davis et al., 1980), or in CSH glucose minimal medium (Miller, 1972) supplemented as described in the text.

Preparation of DNA. Plasmid DNA was prepared by the alkali-hydrolysis method of Ish-Horowitz \& Burke (1981); B. fragilis chromosomal DNA was prepared as follows. Bacterial cells collected from $100 \mathrm{ml}$ of a lateexponential-phase culture (about $10^{9}$ cells $\mathrm{ml}^{-1}$ ) were suspended in $5 \mathrm{ml} 0.01 \mathrm{M}-\mathrm{Tris} / \mathrm{HCl}$ buffer $(\mathrm{pH} 7.8)$ containing $10 \mathrm{~mm}$-EDTA and $8.0 \mathrm{~mm}$-glucose. Streptomyces griseus protease (Merck) $(10 \mathrm{mg})$ and $100 \mathrm{mg}$ SDS were added and gently mixed to dissolve. The resulting cell lysate was extracted with a phenol/chloroform/amyl alcohol (50:49:1, by vol.) mixture (Marmur, 1961), to remove proteins and lipids, until the supernatant was clear. After precipitation with an equal volume of 2-propanol, the pellet was redissolved in $5 \mathrm{ml} 10 \mathrm{mM}-\mathrm{Tris} / \mathrm{HCl}, 1 \mathrm{mM}$ EDTA buffer at pH 7.9 (TE buffer).

Construction of the B. fragilis genomic library and selection of the GS gene. B. fragilis DNA was digested with sufficient Sau3AI restriction endonuclease (Boehringer-Mannheim) to produce a spectrum of DNA fragment sizes, and was then fractionated on a sucrose density gradient. DNA was precipitated from those fractions which were shown by agarose gel electrophoresis to contain fragments of 3-10 kb. Plasmid pEcoR251 was digested to completion with BglII, precipitated with ethanol and redissolved in TE buffer.

After ligation (Davis et al., 1980), DNA was used to transform competent E. coli HB101 cells; transformants containing recombinant pEcoR251 were selected on Luria agar containing Ap $\left(125 \mu \mathrm{g} \mathrm{m}^{-1}\right)$. E. coli HB101 Ap colonies were pooled and recombinant $\mathrm{pEcoR} 251$ plasmid DNA was extracted and used to transform the E. coli YMC-11 gin $A$ deletion mutant. GS transformants were selected on minimal medium containing $\left(\mathrm{NH}_{4}\right)_{2} \mathrm{SO}_{4}$ as the sole nitrogen source. The pJS139 recombinant plasmid was isolated and characterized by restriction mapping using standard procedures (Maniatis et al., 1982).

GS assay. GS activity was assayed in crude cell extracts by the $\gamma$-glutamyltransferase assay which determines the total GS activity (Bender et al., 1977). Specific enzyme activity was expressed as $\mu \mathrm{mol} \gamma$-glutamyl hydroxamate formed $\min ^{-1}$ (mg protein) ${ }^{-1}$.

Protein was determined using the dye-binding method of Bradford (1976).

Regulation of nitrogen metabolism operons. Utilization of arginine and low concentrations of glutamine as sole nitrogen sources $\left(\mathrm{Ntr}^{+}\right.$phenotype) was determined by growth on minimal medium containing glutamine $(0.5 \mathrm{mM})$ or arginine $(15 \mathrm{mM})$ as described by Tuli et al. (1982). Histidase activity was assayed using a modification of the method of Smith et al. (1971). Exponential-phase cells $(2 \mathrm{ml})$ were well mixed with $0.5 \mathrm{ml}$ toluene to permeabilize them. The cells were collected by centrifugation, resuspended in $0.2 \mathrm{ml} 0.15 \mathrm{M}-\mathrm{NaCl}$ and stored at $-60{ }^{\circ} \mathrm{C}$ until 
assayed. For the assay a sample $(20 \mu \mathrm{l})$ was mixed with $100 \mu \mathrm{l} 1 \mathrm{M}$-diethanolamine/ $\mathrm{HCl}$ buffer $(\mathrm{pH} \mathrm{9.4),} \mathrm{10 \mu l}$ freshly made $0.5 \mathrm{M}$ reduced glutathione in $0.1 \mathrm{M}$-potassium phosphate buffer $(\mathrm{pH} \mathrm{7.4)}$ ) and $550 \mu \mathrm{l}$ distilled water. After $5 \mathrm{~min}$ incubation at $37^{\circ} \mathrm{C}, 100 \mu \mathrm{l} 0.1 \mathrm{M}$-histidine was added and mixed; incubation at $37^{\circ} \mathrm{C}$ was then continued for $15 \mathrm{~min}$. The reaction was stopped by addition of $1 \mathrm{ml}$ saturated sodium tetraborate solution. The $A_{277}$ was determined and the specific activity was expressed as $A_{277}$ (mg protein) ${ }^{-1}$ (arbitrary units).

$\beta$-Lactamase assay. The method of Sykes \& Nordström (1972) was used to assay cultures of E. coli YMC-11 (pJS139) growing in minimal and Luria medium. The results are expressed as enzyme units (U) (mg protein) ${ }^{-1}$.

DNA hybridization. Chromosomal DNA extracted from $E$. coli and $B$. fragilis was digested to completion using the restriction endonuclease $\mathrm{XhoI}$; and fragments were then separated by agarose gel electrophoresis in Tris/acetic acid buffer ( $\mathrm{pH} 7 \cdot 8$ ). The DNA fragments were transferred to a nitrocellulose membrane (Hybond-N; Amersham) according to Smith \& Summers (1980). A ${ }^{32}$ P-labelled probe was prepared from purified pJS139 DNA using a nick-translation kit (Amersham) according to the manufacturer's directions. The membrane was treated according to the methods of Meinkoth \& Wahl (1984) for prehybridization and hybridization. Conditions of hybridization were such that a $50 \%$ homology between the probe and chromosomal DNA should have been detected.

Extraction and purification of the pJS139 GS gene product. The enzyme was extracted from E. coli YMC11 (pJS139) cells which had been grown overnight in Luria broth, and which were then diluted into nitrogen-free $\mathrm{CSH}$ minimal medium and shaken at $37^{\circ} \mathrm{C}$ for $2 \mathrm{~h}$. The stabilizer of GS, $N$-cetyl- $N, N, N$-trimethylammonium bromide (Merck), was added to the culture to a final concentration of $0 \cdot 1 \mathrm{mg} \mathrm{ml}^{-1}$; incubation was then continued for $10 \mathrm{~min}$. The cells were collected by centrifugation and resuspended in $1 / 100$ th of the culture volume of extraction buffer ( $50 \mathrm{~mm}$-imidazole $/ \mathrm{HCl}, 20 \mathrm{mM}-\mathrm{MgCl}_{2}, 0.1 \mathrm{mg}$ phenylmethylsulphonyl fluoride $\mathrm{ml}^{-1}$ and $20 \mathrm{~mm}-$ 2-mercaptoethanol, $\mathrm{pH} 7 \cdot 15)$; the cells were then disrupted by sonication. After centrifugation the supernatant was kept on ice; $\mathrm{NaCl}$ was added to $0.1 \mathrm{M}$ and PEG $\left(M_{\mathrm{r}} 6000\right)$ to $4 \%(\mathrm{w} / \mathrm{v})$. After $4 \mathrm{~h}$ the mixture was centrifuged and PEG added to the supernatant to bring it to $6 \%(\mathrm{w} / \mathrm{v})$; the mixture was then kept at $4{ }^{\circ} \mathrm{C}$ overnight.

The pellet was collected, dissolved and loaded onto a Sephacryl S1000 (Pharmacia) $250 \times 10 \mathrm{~mm}$ column, equilibrated and eluted with column buffer $(1 \%, \mathrm{w} / \mathrm{v}, \mathrm{KCl}, 10 \mathrm{~mm}$-imidazole $/ \mathrm{HCl}, \mathrm{pH} 7 \cdot 15)$ at $0.2 \mathrm{ml} \mathrm{min}^{-1}$. Fractions $(1 \mathrm{ml})$ were collected and assayed for GS activity and analysed by SDS-PAGE (Laemmli, 1970; O'Farrell, 1975). Estimates of the cloned GS subunit $M_{\mathrm{r}}$ were obained from $8 \%$ polyacrylamide gels.

Rabbits were immunized by intra-muscular injection of approximately $200 \mu \mathrm{g}$ of the purified GS protein on days $1,3,7,14$ and 21 ; serum was collected on day 24 .

Ouchterlony immunodiffusion plates were prepared (Weir, 1973) using $1 \%$ agarose in $0.1 \mathrm{M}$-Tris/borate buffer (pH 7.8). The central well contained the antiserum $(20 \mu \mathrm{l})$ and the four surrounding wells contained purified cloned GS (1), cell lysate of E. coli YMC-11 (pJS139) (2), cell lysate of E. coli YMC-10 Gln $A^{+}(3)$ and cell lysate of E. coli YMC-11 glnA (4), containing $0 \cdot 28,0.08,0.05$ and 0 units of GS activity, respectively. The cells had been incubated under nitrogen-limiting conditions before lysis. After precipitin bands were apparent, the agarose gel was washed for $4 \mathrm{~h}$ in running water, dried onto Gelbond film (FMC Corp.), stained with aceto-orcein ( $2 \mathrm{~g}$ orcein in $100 \mathrm{ml} 50 \%, \mathrm{v} / \mathrm{v}$, acetic acid) and destained in absolute alcohol.

Western blotting from SDS-PAGE gels onto nitrocellulose membranes was done by the method of Towbin et al. (1979): the membrane was blocked with $10 \mathrm{mM}-\mathrm{Tris} / \mathrm{HCl}(\mathrm{pH} \mathrm{7.4)}, 0 \cdot 15 \mathrm{M}-\mathrm{NaCl}, 2 \%(\mathrm{w} / \mathrm{v})$ nonfat dried milk (Johnson et al., 1984) and $0.05 \%(\mathrm{v} / \mathrm{v})$ Tween-20 overnight at room temperature. The antibody binding and the development of bands using a goat anti-rabbit serum conjugated to horseradish peroxidase was done according to Rybicki \& von Wechmar (1982), except that Tween-20 was used in place of NP-40.

\section{RESULTS}

\section{Cloning of the B. fragilis GS gene in E. coli}

A library of $B$. fragilis DNA was established in $E$. coli $\mathrm{HB} 101$ by insertional inactivation of the EcoRI gene of pEcoR251. Plasmid DNA prepared from pools of clones (about 10000) containing $B$. fragilis DNA was used to transform the $E$. coli YMC-11 $\mathrm{GlnA}^{-} \mathrm{NtrB}^{-} \mathrm{NtrC}^{-}$ deletion strain. An $E$. coli $\mathrm{YMC}-11 \mathrm{Gln} \mathrm{A}^{+}$transformant was isolated on minimal medium. The transformant contained a recombinant pEcoR251 plasmid.

The presence of a GS structural gene on this plasmid was confirmed by retransformation of $E$. coli $\mathrm{YMC}_{-11} \mathrm{Gln}^{-} \mathrm{NtrB}^{-} \mathrm{NtrC}^{-}$and $E$. coli $\mathrm{ET}$ (8051 $\mathrm{Gln}^{-} \mathrm{NtrB}^{-} \mathrm{NtrC}^{-}$deletion strains. After transformation approximately equal numbers of colonies were obtained on minimal medium $\left(G \ln \mathrm{A}^{+}\right)$and Luria medium containing $\mathrm{Ap}\left(\mathrm{Ap} \mathrm{p}^{\mathrm{r}}\right)$. This recombinant plasmid was designated pJS139. Digestion of pJS139 with PstI indicated that an approximately 8 kb DNA fragment was inserted into pEcoR251 (Fig. 1). 


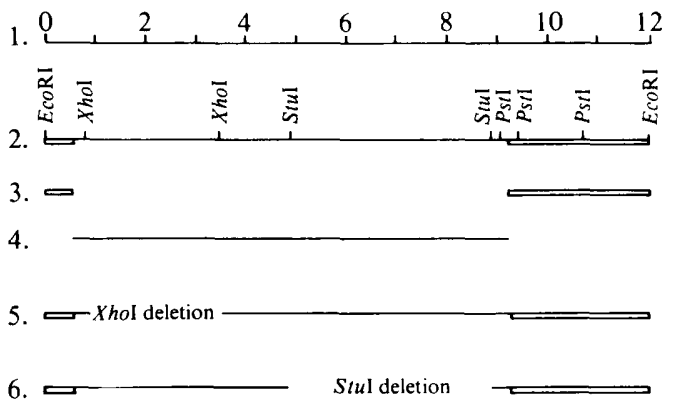

Fig. 1. Partial restriction and deletion map of pJS139. 1, Scale (kb);2, pJS139 $\mathrm{Ap}^{r} \mathrm{GlnA}^{+}$; 3, pEcoR251 Ap $;$ 4, B. fragilis fragment; 5, pJS139.1 Ap ${ }^{r} \mathrm{Gln} \mathrm{A}^{-}$(XhoI deletion); 6, pJS139.2 $\mathrm{Ap}^{r} \mathrm{GlnA}^{+}$ (StuI deletion).

(a)

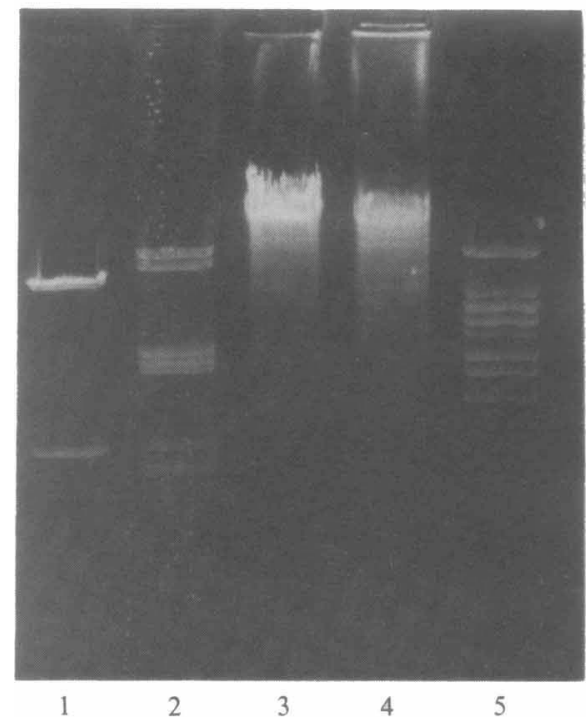

(b)

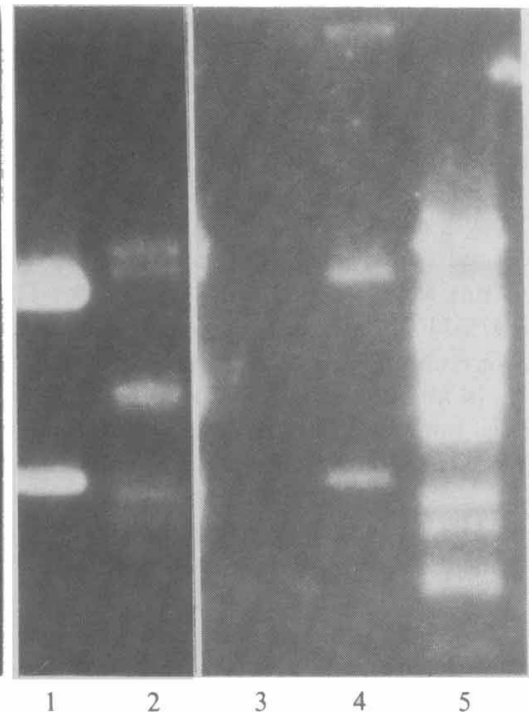

Fig. 2. Hybridization of ${ }^{32}$ P-labelled pJS139 with $B$. fragilis and E. coli DNA. (a) Ethidium-bromidestained agarose gel electrophoresis of restriction digests of plasmid and chromosomal DNA: lane 1, pJSI39-XhoI; 2, $\lambda$-PstI; 3, E. coli HB101-XhoI; 4, B. fragilis BF-1-XhoI; 5, $\lambda$-BstEII. (b) Autoradiograph of a Southern blot of the gel in (a): lanes 1 and 2, $24 \mathrm{~h}$ exposure; lanes 3,4 and $5,48 \mathrm{~h}$ exposure. The hybridization probe was ${ }^{32} \mathrm{P}$-labelled pJS139, to which ${ }^{32} \mathbf{P}$-labelled $\lambda$ DNA was added as an internal reference.

\section{Characterization of the recombinant plasmid pJS139}

The restriction map of pJS139 was obtained by complete single or double digestions with restriction endonucleases (Fig. 1). The location of the DNA region determining the Gln $A^{+}$ phenotype was determined by the isolation of pJS139 deletion plasmids. The GS gene was located within a $4.2 \mathrm{~kb}$ fragment of the $8 \mathrm{~kb}$ insert, which was close to the junction of the $B$. fragilis DNA insert and the pEcoR251 DNA. Excision of a $2.7 \mathrm{~kb}$ fragment of DNA from this region using $X h o I$ abolished the $G \ln A^{+}$phenotype (pJS139.1), while excision of a $4.0 \mathrm{~kb}$ plasmid fragment bounded by StuI restriction sites (pJS139.2) did not cause the loss of the GlnA ${ }^{+}$ phenotype.

The origin of the $8 \mathrm{~kb}$ insert in pJS139 was determined by Southern blotting and DNA hybridization between $B$. fragilis chromosomal DNA and ${ }^{32} \mathrm{P}$-labelled pJS139 (Fig. 2). The 
Table 2. Relative levels of GS and histidase activity

\begin{abstract}
Strains were grown in CSH glucose minimal medium (Miller, 1972) with 15 mm-glutamate as nitrogen source and then diluted in minimal medium supplemented as follows: $\mathrm{H}, 15 \mathrm{~mm}$-glutamate, $15 \mathrm{~mm}$ glutamine; $\mathrm{L}, 15 \mathrm{~mm}$-glutamate, $0.15 \mathrm{~mm}$-glutamine; $\mathrm{N}, 1 \mathrm{~g}\left(\mathrm{NH}_{4}\right)_{2} \mathrm{SO}_{4} \mathrm{1}^{-1}$ in $\mathrm{CSH}$ minimal medium; $\mathrm{F}$, nitrogen-free $\mathrm{CSH}$ minimal medium. Samples were assayed after $3 \mathrm{~h}$ incubation at $37^{\circ} \mathrm{C}$ in shake flasks. Histidase activity is defined in Methods. GS activity is expressed as $\mu$ mol $\gamma$-glutamyl hydroxamate formed $\min ^{-1}(\mathrm{mg} \text { protein })^{-1}$. SEM values were $5-10_{0}^{\circ}$ of the values in the Table.
\end{abstract}

\begin{tabular}{|c|c|c|c|c|c|c|c|}
\hline \multirow[b]{2}{*}{ Strain } & \multicolumn{4}{|c|}{ GS activity } & \multicolumn{3}{|c|}{ Histidase activity } \\
\hline & $\mathrm{H}$ & $\mathrm{L}$ & $N$ & $\mathrm{~F}$ & $\mathrm{H}$ & $\mathrm{L}$ & $\mathbf{F}$ \\
\hline $\begin{array}{l}\text { YMC-10 Gln } \mathrm{A}^{+} \mathrm{Ntr}^{+} \\
\text {YMC-11 glnA ntr } \\
\text { YMC-11 pJS } 139 \mathrm{Gln} \mathrm{A}^{+} n t r\end{array}$ & $\begin{array}{l}0 \cdot 08 \\
0 \\
0\end{array}$ & $\begin{array}{l}1 \cdot 24 \\
0 \\
0 \cdot 05\end{array}$ & $\begin{array}{l}1 \cdot 1 \\
0 \\
1.25\end{array}$ & $\begin{array}{l}2 \cdot 49 \\
0 \\
4 \cdot 15\end{array}$ & $\begin{array}{r}12 \cdot 55 \\
6 \cdot 35 \\
7 \cdot 65\end{array}$ & $\begin{array}{c}24 \cdot 25 \\
6 \cdot 65 \\
6 \cdot 6\end{array}$ & $\begin{array}{l}32 \cdot 85 \\
15 \cdot 55 \\
14 \cdot 3\end{array}$ \\
\hline
\end{tabular}

plasmid pJS139 has two XhoI fragments of approximately 9.3 and $2.7 \mathrm{~kb}$. The $2.7 \mathrm{~kb}$ fragment is internal to the putative $B$. fragilis $g \ln A$ insert, but is adjacent to the junction between the vector and insert DNA. Therefore ${ }^{32} \mathrm{P}$-labelled pJSI 39 was hybridized to both $B$. fragilis chromosomal DNA and pJS139 digested with $X h o I$ : a positive $2.7 \mathrm{~kb}$ hybridization signal was detected in both digests (Fig. $2 a$, lanes 2 and 5). A second band of hybridization of approximately $10 \mathrm{~kb}$ was also observed. No DNA hybridization was detected between ${ }^{32} \mathrm{P}$-labelled pJS139 and a XhoI digest of chromosomal DNA from the $E$. coli $\mathrm{HB} 101 \mathrm{~g} \ln \mathrm{A}^{+}$strain.

\title{
Regulation of the cloned GS activity
}

GS activity was readily detectable in $E$. coli YMC-11 containing pJS139 and E. coli YMC-10 grown under nitrogen-limiting conditions. while no GS activity was detected in extracts of $E$. coli YMC-11 or ET8051 grown under any conditions (Table 2).

GS activity in E. coli YMC-11 containing pJS139 was partly repressed by ammonium salts but was fully repressed by glutamate and glutamine. GS activity of the E. coli YMC-10 wild-type strain was partly repressed by glutamate and ammonium salts but was fully repressed by glutamine (Table 2).

In $E$. coli and Salmonella typhimurium the $n \operatorname{tr} B$ and $n \operatorname{tr} C$ genes, which are closely linked to the GS gene, regulate not only the GS gene but also a high-affinity glutamine and a high-affinity arginine transport system (Kustu et al., 1979). These ntr genes also activate the histidine utilization operon (Magasanik, 1982).

The ability of the various $E$. coli strains to grow on minimal medium containing low concentrations of arginine and glutamine was determined: while the ET8051 and YMC-11 $g \ln A$ deletion strains were unable to grow on these media, when these strains contained the recombinant plasmid pJS139 very weak growth was obtained. In comparison, the YMC-10 $g \ln A^{+} n t r B^{+} n t r C^{+}$strain grew well under these conditions.

The E. coli strains YMC-10 and YMC-11 carry a Klebsiella aerogenes hut operon (Tuli et al., 1982) that has a hutC mutation resulting in high basal levels of histidase. The results in Table 2 show that this enzyme level was increased in the YMC-10 strain by the $n t r B$ and $n t r C$ coregulation of the hut operon (Tuli et al., 1982) in low concentrations of glutamine, but that this was not observed with the YMC-11 $g \ln A \operatorname{ntr} B \operatorname{ntr} C$ or the YCM-11(pJS139) $g \ln A^{+}$strains. Increased levels of histidase were observed with all strains when cells were suspended in nitrogen-free minimal medium.

The $\beta$-lactamase activities of $E$. coli YMC-11(pJS139) grown in minimal medium with and without glutamine $(15 \mathrm{mM})$ were similar $\left(35.1\right.$ and 37.8 units $\mathrm{mg}^{-1}$ respectively).

\section{Purification of the cloned GS gene product}

The specific activity of GS increased during the purification which resulted in a 280 -fold purification of the enzyme (Table 3 ). GS activity was not precipitated by $4 \%(w / v)$ PEG under 


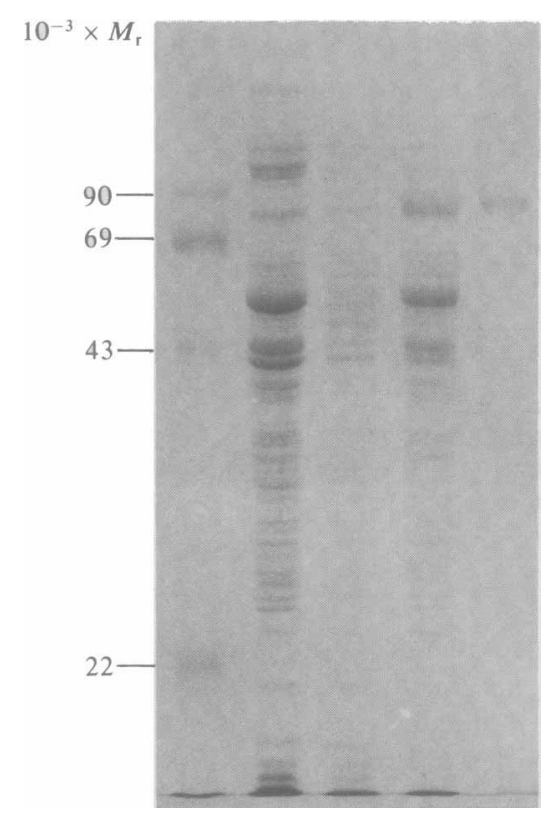

Fig. 3. SDS-PAGE of cell extracts and purified, cloned GS from E. coli cells. The gel contained $10 \%$ $(\mathrm{w} / \mathrm{v})$ polyacrylamide and was $0.5 \mathrm{~mm}$ thick. After electrophoresis as described in Methods it was stained with Coomassie brilliant blue. The samples were reduced and treated with SDS to remove secondary and tertiary structures. Lane $1, M_{\mathrm{r}}$ markers; lane $2, E$. coli YMC-10 cell lysate $(20 \mu \mathrm{g})$; lane 3 , $E$. coli YMC-11 cell lysate $(10 \mu \mathrm{g})$; lane $4, E$. coli YMC-11(pJS139) cell lysate $(20 \mu \mathrm{g})$; lane 5, peak GS activity fraction from Sephacryl S-1000 $(\sim 1 \mu \mathrm{g})$.

Table 3. Purification of the cloned B. fragilis GS enzyme from E. coli YMC-11(pJS139)

Total GS activity was determined by the $\gamma$-glutamyl transferase assay. The details of the purification and assay procedures are described in Methods. GS activity is expressed as $\mu$ mol $\gamma$-glutamyl hydroxamate $\min ^{-1}$. Fraction 1 and fraction 5 correspond to lanes 3 and 5 of Fig. 3 .

\begin{tabular}{|c|c|c|c|c|c|}
\hline Fraction & $\begin{array}{l}\text { Vol. } \\
(\mathrm{ml})\end{array}$ & $\begin{array}{l}\text { Total } \\
\text { protein } \\
(\mathrm{mg})\end{array}$ & $\begin{array}{c}\text { Total } \\
\text { GS activity }\end{array}$ & $\begin{array}{c}\text { Specific } \\
\text { GS activity } \\
\text { (per mg protein) }\end{array}$ & $\begin{array}{c}\text { Purification } \\
\text { (-fold) }\end{array}$ \\
\hline 1. Ultrasonic extract & 25 & 175 & $62 \cdot 5$ & $0 \cdot 36$ & 1 \\
\hline 2. $4 \%$ PEG supernatant & 25 & 152.5 & $59 \cdot 4$ & $0 \cdot 39$ & 1.09 \\
\hline $3.6 \%$ PEG supernatant & 25 & 131 & $10 \cdot 2$ & 0.08 & 0.22 \\
\hline 4. $6 \%$ PEG precipitate & $1 \cdot 5$ & 36 & 133.9 & 3.72 & $10 \cdot 41$ \\
\hline 5. S-1000 peak & $1 \cdot 0$ & 0.7 & 71 & $101 \cdot 4$ & $284 \cdot 3$ \\
\hline
\end{tabular}

these conditions but was precipitated by $6 \%(\mathrm{w} / \mathrm{v}) \mathrm{PEG}$. It was necessary to increase the $\mathrm{pH}$ of the solution in which the $6 \% \mathrm{PEG}$ pellet was resuspended to $\mathrm{pH} 8.0$ to dissolve the pellet. An increase in total GS activity following $6 \%$ PEG precipitation was observed.

SDS-PAGE of cell lysates showed an increase in the $M_{\mathrm{r}} 75-90000$ protein content of crude cell extracts of $E$. coli YMC-11 (pJS139), but not in extracts from E. coli YMC-10 wild-type or YMC$11 \mathrm{G} \ln \mathrm{A}^{-}$strains. This is the protein which is purified after Sephacryl chromatography (Fig. 3). Electrophoresis in $8 \%$ SDS-PAGE showed the apparent $M_{\mathrm{r}}$ of this polypeptide to be approximately 75000 .

Rabbit antibodies to this protein gave a single band in an Ouchterlony plate and showed homology to a single protein in a crude extract of the E. coli YMC-11(pJS139) strain, but no cross-reaction with cell extracts from $E$. coli $\mathrm{YMC}^{-10} \mathrm{G} \ln \mathrm{A}^{+}$or $\mathrm{YMC}^{-11} \mathrm{Gln}^{-}$was observed. 
Western blot analysis showed a weak cross-reactivity between the antiserum prepared against the purified cloned $B$. fragilis GS and a polypeptide of the same $M_{\mathrm{r}}$ as $E$. coli GS.

\section{DISCUSSION}

A cloned B. fragilis $g \ln A$ gene was shown to function in $E$. coli $\mathrm{Gln}^{-}$deletion mutants: this is the first report of the expression of a gene from the medically important, obligate anaerobe, $B$. fragilis in $E$. coli.

The origin of the $g \ln A$ gene was confirmed by DNA hybridization. The gene directed the synthesis in $E$. coli glutamine auxotrophs of a $B$. fragilis GS which was enzymically active.

The cloned GS gene appeared to be expressed from a promoter contained within the inserted $B$. fragilis DNA segment of pJS139 as it is unlikely that a plasmid promoter would be regulated by nitrogen levels. In addition, $E$. coli YMC-11(pJS139) containing $\mathrm{pcI}_{857} \mathrm{Kan}^{\mathrm{r}}$ and $\lambda$ repressor(ts), produced the same levels of GS per mg of protein when incubated in nitrogen-free minimal medium at $23{ }^{\circ} \mathrm{C}$ and $39^{\circ} \mathrm{C}$, which indicated that the cloned $B$. fragilis gln $A$ gene was not expressed from the rightward $\lambda$-promoter present on the vector.

The purified $B$. fragilis GS subunit had an apparent $M_{\mathrm{r}}$ of approximately 75000 . Assuming that the enzyme is the typical dodecamer, then the particle $M_{\mathrm{r}}$ for the undissociated GS would be approximately 900000 , a value larger than that reported for other bacteria. E. coli, Bacillus subtilis, Rhizobium japonicum and Vibrio alginolyticus have subunits with $M_{\mathrm{r}}$ values of 50000 , 56000,60000 and 60000 respectively (Stadtman \& Ginsberg, 1974; Deuel et al., 1970; Bhandari et al., 1983; Bodasing et al., 1985).

DNA hybridization experiments indicated that there was less than $50 \%$ DNA homology between the $B$. fragilis $g \ln A$ gene and the $E$. coli $g \ln A$ gene. Although no cross-reactivity was detected by the Ouchterlony immunoprecipitation, Western blotting detected weak crossreactivity between antiserum raised to the purified cloned $B$. fragilis GS and $E$. coli GS. Lack of DNA homology but antigenic cross-reactivity was reported for the $g \ln A$ gene cloned from the Gram-negative chemolithotroph Thiobacillus ferrooxidans and the E. coli glnA gene and GS (Barros et al., 1985, 1986). These observations extend the findings that GS enzymes from Gramnegative bacteria are antigenically related (Tronick et al., 1973).

The $B$. fragilis $g \ln A$ gene was subject to nitrogen repression in $E$. coli. The regulation by nitrogen affected the $g \ln A$ gene and was not due to an increase in plasmid copy number as a result of growth in the different media. The levels of another plasmid gene product, $\beta$-lactamase, produced by $E$. coli YMC-11 (pJS139) and assayed after growth on the different nitrogen media, did not show any variation [35-38 $\mathrm{U}\left(\mathrm{mg}^{\mathrm{p}}\right.$ protein $\left.^{-1}\right)$ ] in the samples assayed.

The regulation of the cloned $B$. fragilis $g \ln A$ gene differed from the regulation of the $E$. coli $g \ln A$ gene in the wild-type strain: the cloned $B$. fragilis $g \ln A$ gene was repressed by glutamate whereas the $E$. colig $\ln A$ gene was expressed in the presence of glutamate. Since the $g \ln A$ gene on pJS139 was regulated by nitrogen it is suggested that some nitrogen regulatory activities are located on pJS139 but that these activities are not directly analogous to the $n \operatorname{tr} B$ and $n \operatorname{tr} C$ system of the enteric bacteria.

In comparison with the $E$. coli wild-type strain the cloned $B$. fragilis DNA fragment only enabled weak growth of the $E$. colig $\ln A \operatorname{ntr} B \operatorname{ntr} C$ deletion mutant on media containing arginine or low concentrations of glutamate as sole sources of nitrogen and it was not able to activate the Klebsiella hut operon in E. coli YMC-11.

We wish to thank Dr M. M. Zabeau for gifts of plasmid DNA used in this project and Harold Zappe for technical assistance and advice.

\section{REFERENCES}

Anderson, B. L., Bills, M. M., Egerton, J. R. \& MATTICK, J. S. (1984). Cloning and expression in Escherichia coli of the gene encoding the structural sub-unit of Bacteroides nodosus fimbriae. Journal of Bacteriology 160, 748-754.
Backman, K., Chen, Y.-M. \& Magasanik, B. (1981). Physical and genetic characterization of the $g \ln A-$ $g \ln G$ region of the Escherichia coli chromosome. Proceedings of the National Academy of Sciences of the United States of America 78, 3743-3747. 
Barros, M. E. C., Rawlings, D. E. \& Woods, D. R. (1985). Cloning and expression of the Thiobacillus ferrooxidans glutamine synthetase gene in Escherichia coli. Journal of Bacteriology 164, 1386-1389.

Barros, M. E. C., Rawlings, D. E. \& Woods, D. R. (1986). Purification and regulation of a cloned Thiobacillus ferrooxidans glutamine synthetase cloned in Escherichia coli. Journal of General Microbiology 132, 1989-1995.

Bender, R. A., Janssen, K. A., Resnick, A. D., BlumenberG, M., FoOR, F. \& MAgasaniK, B. (1977). Biochemical parameters of glutamine synthetase from Klebsiella aerogenes. Journal of Bacteriology 129, $1001-1009$.

Bhandari, B., Vairinhos, F. \& Nicholas, D. J. D. (1983). Some properties of glutamine synthetase from Rhizobium japonicum CC705 and CC723. Archives of Microbiology 136, 84-88.

Bodasing, S. J., BRANDT, P. W., RobB, F. T. \& WoOds, D. R. (1985). Purification and regulation of glutamine synthetase in a collagenolytic Vibrio alginolyticus strain. Archives of Microbiology 140, 369-374.

BRADFORD, M. M. (1976). A rapid and sensitive method for the quantitation of microgram quantities of protein utilizing the principle of protein-dye binding. Analytical Biochemistry 72, 248-254.

Crosby, B. \& Collier, B. (1984). Cloning and expression in Escherichia coli of cellulase genes from Bacteroides succinogenes. Applied Science 27, 573576.

Davis, R. W., Botstein, D. \& Roth, J. R. (1980). Advanced Bacterial Genetics. Cold Spring Harbor, New York: Cold Spring Harbor Laboratory.

Deuel, T. F., Ginsburg, A., Yeh, J., Shelton, E. \& Stadman, E. R. (1970). Bacillus subtilis glutamine synthetase. Journal of Biological Chemistry 245, 5195-5205

Elleman, T. C. \& Hoyne, P. A. (1984). Isolation of the gene encoding pilin of Bacteroides nodosus (strain 198): the causal organism of ovine foot rot. FEBS Letters 173, 103-107.

Garcia, E., Bancroft, S., Rhee, S. G. \& Kustu, S (1977). The product of a newly identified gene, $g \ln F$, is required for synthesis of glutamine synthetase in Salmonella. Proceedings of the National Academy of Sciences of the United States of America 74, 1662 1666.

Guiney, D. G., Hasegawa, P. \& Davis, C. E. (1984). Plasmid transfer from Escherichia coli to Bacteroides fragilis: differential expression of antibiotic resistance phenotypes. Proceedings of the National Academy of Sciences of the United States of America 81, $7203-7206$.

Guthrie, E. P., Shoemaker, N. B. \& Salyer, A. A. (1985). Cloning and expression in Escherichia coli of a gene coding for a chondroitin lyase from Bacteroides thetaiotaomicron. Journal of Bacteriology 164, $510-515$.

Ish-Horowitz, D. \& Burke, J. F. (1981). Rapid and efficient cosmid cloning. Nucleic Acids Research 9, $2989-2998$.

Johnson, D. A., Gautsch, J. W., Sportsman, J. R. \& ELDER, J. H. (1984). Improved technique utilizing nonfat dry milk for analysis of proteins and nucleic acids transferred to nitrocellulose. Genetic Analytical Techniques 1, 3-8.
Kasper, D. J., Onderdonk, A. B., Polk, B. F. \& Bartlett, J. G. (1979). Surface antigens as virulence factors in infection with Bacteroides fragilis. Reviews of Infectious Diseases 1, 278-288.

Kustu, S., McFarland, N., Hui, S. P., Esmon, B. \& AMES, G. F. (1979). Nitrogen control in Salmonella: co-regulation of synthesis of glutamine synthetase and amino acid transport systems. Journal of Bacteriology 138, 218-234.

LAEMmLI, U. K. (1970). Cleavage of the structural proteins during assembly of the head of bacteriophage T4. Nature, London 277, 680-685

MaGasanIK, B. (1982). Genetic control of nitrogen assimilation in bacteria. Annual Review of Genetics 16, 135-168.

Maniatis, T., Fritsch, E. F. \& SambrooK, J. (1982). Molecular Cloning: A Laboratory Manual. Cold Spring Harbor, New York: Cold Spring Harbor Laboratory

MARMUR, J. (1961). A procedure for the isolation of deoxyribonucleic acid from micro-organisms. Journal of Molecular Biology 3, 208-218.

MCFarland, N., MCCarter, L., ARTZ, S. \& Kustu, $\mathrm{S}$. (1981). Nitrogen regulation locus $g \ln R$ of enteric bacteria is composed of cistrons $n \operatorname{tr} B$ and $n \operatorname{tr} C$ : identification of their products. Proceedings of the National Academy of Sciences of the United States of America 78, 2135-2139.

MEINKOTH, J. \& WAHL, G. (1984). Hybridization of nucleic acids immobilized on solid supports. Analytical Biochemistry 138, 267-284.

Miller, J. H. (1972). Experiments in Molecular Genetics. Cold Spring Harbor, New York: Cold Spring Harbor Laboratory.

Mossie, K. G., Jones, D. T., RobB, F. T. \& Woods, D. R. (1979). Characterization and mode of action of a bacteriocin produced by a Bacteroides fragilis strain. Antimicrobial Agents and Chemotherapy 16, 724-730.

O'FARrel, P. H. (1975). High resolution two-dimensional electrophoresis of proteins. Journal of Biological Chemistry 250, 4007-4021.

Pahel, G. \& Tyler, B. (1979). A new glnA-linked regulatory gene for glutamine synthetase in Escherichia coli. Proceedings of the National Academy of Sciences of the United States of America 76, 45444548 .

Remaut, E., TSAO, H. \& Fiers, W. (1983). Improved plasmid vectors with thermo-inducible expression and temperature regulated runaway replication. Gene 22, 103-113.

RYBICKI, E. P. \& VON WECHMAR, M. B. (1982). Enzyme assisted immune detection of plant virus proteins electroblotted onto nitrocellulose paper. Journal of Virological Methods 5, 267-278.

Smith, G. E. \& Summers, M. D. (1980). Recovery of DNA from gels. Analytical Biochemistry 109, 123129.

SMith, G. R., HALPERN, Y. S. \& MAGASANIK, B. (1971). Genetic and metabolic control of enzymes responsible for histidine degradation in Salmonella typhimurium. Journal of Biological Chemistry 246, 33203329.

Southern, J. A., Katz, W. \& Woods, D. R. (1984). Purification and properties of a cell-bound bacteriocin from a Bacteroides fragilis strain. Antimicrobial Agents and Chemotherapy 25, 253-257. 
Stadtman, E. R. \& Ginsburg, A. (1974). The glutamine synthetase of Escherichia coli: structure and control. In The Enzymes, 3rd edn, vol. 10, pp. 755-807. Edited by P. D. Boyer. New York Academic Press

Streicher, S. L. \& TYler, B. (1980). Purification of glutamine synthetase from a variety of bacteria. Journal of Bacteriology 142, 69-78.

SYKeS, R. B. \& NoRdSTRÖM, K. (1972). Microiodometric determination of $\beta$-lactamase activity. Antimicrobial Agents and Chemotherapy 1, 94-99.

Towbin, H., Staehelin, T. \& Gordon, J. (1979) Electrophoretic transfer of proteins from polyacrylamide gels to nitrocellulose sheets: procedure and some applications. Proceedings of the National Academy of Sciences of the United States of America 76, 4350-4354.
Tronick, S. R., Clardi, J. E. \& Stadtman, E. R. (1973). Comparative biochemical and immunological studies of bacterial glutamine synthetases. Journal of Bacteriology 115, 858-868.

Tuli, R., Fisher, R. \& HASElKorn, R. (1982). The ntr genes of Escherichia coli activate the hut and nif operons of Klebsiella pneumoniae. Gene 19, 109116.

WEIR, D. M. (Editor) (1973). Handbook of Experimental Immunology, 2nd edn, vol. 1, pp. 19.13-19.22. Oxford: Blackwell Scientific Publications.

Zabeau, M. \& Stanley, K. K. (1982). Enhanced expression of cro- $\beta$-galactosidase fusion proteins under the control of the $P_{R}$ promoter of the bacteriophage lambda. EMBO Journal 1, 12171224. 